\title{
Nitrification and nitrogen mineralization in agricultural soils contaminated by copper mining activities in Central Chile
}

Héctor Moya ${ }^{1}$, José Verdejo ${ }^{1}$, Carolina Yáñez ${ }^{2}$, Juan E. Álvaro ${ }^{1}$, Sébastien Sauvé ${ }^{3}$ and Alexander Neaman ${ }^{*}$

${ }^{1}$ Pontificia Universidad Católica de Valparaíso, Escuela de Agronomía, Quillota, Chile. ${ }^{2}$ Pontificia Universidad

Católica de Valparaíso, Instituto de Biología, Valparaíso, Chile. ${ }^{3}$ Université de Montréal, Department of Chemistry, H3C 3J7, Montréal, QC, Canada. *Corresponding author: alexander.neaman@pucv.cl

\begin{abstract}
Microbiological bioassays of nitrification and nitrogen mineralization have been used for evaluation of soil quality on metal-contaminated soils. We evaluated the effectiveness of nitrification and nitrogen mineralization bioassays as quality indicators of soil degradation caused by metal contamination. We performed standard tests based on protocols of ISO 14238 (2012) and ISO 15685 (2012) on 90 soil samples collected from agricultural areas in central Chile that were historically contaminated by mining activities. Potential nitrification rate (PNR) was best explained by $\mathrm{pH}$ and organic matter content $(\mathrm{OM})\left(\mathrm{R}^{2}=0.32\right)$, while nitrogen mineralization (Nmin) was best explained by $\mathrm{OM}$ and clay content $\left(\mathrm{R}^{2}=0.44\right)$. Following normalization of the bioassays responses with respect to $\mathrm{OM}$ yielded significant correlations between $\mathrm{PNR}$ and $\mathrm{pH}$ and total $\mathrm{Cu}$ content $\left(\mathrm{R}^{2}=0.22\right)$, and between Nmin and clay and total $\mathrm{Cu}$ contents $\left(\mathrm{R}^{2}=0.19\right)$. However, inasmuch as total $\mathrm{Cu}$ content improved the regression model showing the inhibitory effect of $\mathrm{Cu}$ in both bioassays, it accounted for a mere small proportion of the variance. This was despite the wide range of $\mathrm{Cu}$ contents in the soils studied (51-2878 $\mathrm{mg} \mathrm{kg}^{-1}$ ). Hence, due to the known sensitivity of the nitrification and nitrogen mineralization process to physicochemical characteristics of soils, these bioassays seem to have limited applicability for metal toxicity assessment in metalcontaminated soils.
\end{abstract}

Keywords: Copper toxicity, nitrification potential, nitrogen mineralization, soil quality 


\section{Introduction}

Chile is the leader in the production of copper in the world (Comisión Chilena del Cobre, www.cochilco. cl). Environmental problems associated with copper mining in Central Chile are widely known, particularly in relation to the historical contamination of agricultural soils with metals, such as $\mathrm{Cu}, \mathrm{Cd}, \mathrm{Pb}$ and $\mathrm{Zn}$, and metalloids (As) that will be henceforth referred to as "metals" for convenience (De Gregori et al., 2003, Verdejo et al., 2015). It is well known that soil contamination with metals diminishes its quality and presents a risk for soil functioning (Adriano, 2001).

Soil microbial properties are being increasingly used as indicators of soil quality (Garbisu et al., 2011). They provide an early and integrated measure of soil functioning, which cannot be obtained with physicochemical measures and/or analyses of diversity of higher organisms (Nielsen et al., 2002). Another reason to use microbial properties as indicators of soil quality is the importance of microorganisms in cycling nutrients and, thus, maintaining soil fertility (ISO 14238, 2012).

In particular, bioassays of nitrification and nitrogen mineralization are recommended in a minimum test battery for the assessment of soil quality (ISO 17402, 2008). The oxidation of ammonium to nitrite (nitrification process) is particularly sensitive to chemicals (ISO 15685, 2012). Hansson et al. (1991) described inhibitory effects of pesticides on the potential nitrification rate (PNR) and recommended its use for assessment of long-term effects of pesticides on soil quality. Based on this study, ISO 17402 (2008) considers PNR as a validated bioassay for assessment of soil quality. On the other hand, nitrogen mineralization (Nmin) is one of the most important microbial processes in soils, since any long-term interference with this process influences soil fertility (ISO 14238,
2012). However, Nmin is not validated for assessment for soil quality (ISO 17402, 2008).

International protocols recommend the use of artificial-contaminated soils with solutions of metals at increasing concentrations (metal-spiked soils) (ISO 14238, 2012, ISO 15685, 2012). However, this approach has been criticized, because the effects observed after soil spiking with metals reflect sudden disturbance of microbiological processes (Giller et al., 1998). For example, Oorts et al. (2006) indicated that in field-contaminated soil, toxicity thresholds of $\mathrm{Cu}$ for nitrifying microorganisms are higher than in metal-spiked soils. Similarly, the study of Smolders et al. (2003) reveals a discrepancy in $\mathrm{Zn}$ toxicity to microbial responses between metal-spiked and fieldcontaminated soils.

Although the importance of using field-contaminated soils for metal toxicity tests is evident (Giller et al., 2009), the use of these soils presents several difficulties. In particular, microbial processes are sensitive to soil $\mathrm{pH}$ (Smolders et al., 2004). Specifically, Smolders et al. (2001) indicated that soil pH (average of $5.4 \pm 1.5$ ) is the main variable determining the PNR of non-contaminated soils. Likewise, Sauvé et al. (1999) found that $\mathrm{pH}$ (average of $6.3 \pm 1.2$ ) is a significant variable determining PNR in field-contaminated soils. These authors reported that the nitrification process was inhibited at $\mathrm{pH}$ values below 5.6 and 6.0, respectively. In addition, Sauvé et al. (1999) indicate that optimal $\mathrm{pH}$ is between 6.5 and 7.5. However, as it was reported by Verdejo et al. (2015), field-contaminated soils from central Chile have a $\mathrm{pH}$ predominantly circumneutral (average of $7.0 \pm 0.5$ ). Therefore, we hypothesized that PNR and $\mathrm{Nmin}$ in agricultural areas historically contaminated by mining activities in central Chile would not be excessively affected by soil $\mathrm{pH}$. 
Furthermore, microbial processes are also dependent of organic matter $(\mathrm{OM})$ content, making it difficult to interpret the data of field-contaminated soils (Smolders et al., 2004). Higher OM may lead to higher microbial biomass and activities. Thus, in order to compare between different soils and evaluate the effect of metals on microbial properties, it is recommended to normalize microbial properties by OM (Bhattacharyya et al., 2008). Therefore, we hypothesized that the responses of PNR and Nmin normalized by OM would not be affected by OM, revealing the effect of metals on nitrification and nitrogen mineralization. Thus, this research aims to evaluate the effectiveness of the bioassays of nitrification and nitrogen mineralization as quality indicators in agricultural soils historically contaminated by mining activities in Central Chile.

\section{Materials and Methods}

\subsection{Study sites}

Top soils of 90 agricultural areas historically contaminated by mining activities in central Chile were studied. Sampling points (See Online Supplementary Table 1 in Online Supplementary Material: http:// www.webcitation.org/6pnWwO9Kh) were chosen based on prior knowledge on the spatial distribution of $\mathrm{Cu}$ in the soils of the Aconcagua River basin and the Puchuncaví Valley (Aguilar et al., 2011, Gonzalez et al., 2015). The sites and sampling points were chosen with the aim of obtaining a wide range of total metal concentrations.

\subsection{Physicochemical characterization of soils}

Approximately $10 \mathrm{~kg}$ of soil were collected from the 0-20 cm layer. Samples were sieved through a $2 \mathrm{~mm}$ mesh and then homogenized in a cement mixer with an inner plastic cover. The mixer was washed between samples to avoid cross contamination.

For microbiological analyses, the samples were stored at $4{ }^{\circ} \mathrm{C}$ in sealed plastic bags (Stenberg et al., 1998). In order to determine the general physicochemical characteristics of the soils, a subsample of $1 \mathrm{~kg}$ from each sample was separated. Each subsample was dried at $40{ }^{\circ} \mathrm{C}$ for 48 hours. The general physicochemical characteristics of the soils (electrical conductivity, $\mathrm{pH}$, organic matter content, $\mathrm{C} / \mathrm{N}$ ratio and texture) were determined using routine methods (Table 1) (Sheldrick and Wang, 1993, Sparks et al., 1996).

Concentrations of soluble $\mathrm{Cu}, \mathrm{Cd}, \mathrm{Pb}, \mathrm{Zn}$ and $\mathrm{As}$ were determined using a solution of $0.1 \mathrm{M} \mathrm{KNO}_{3}$ as extractant (Stuckey et al., 2008). In order to determine total $\mathrm{Cu}, \mathrm{Cd}, \mathrm{Pb}, \mathrm{Zn}$ and $\mathrm{As}$, the samples were digested in boiling nitric acid followed by perchloric acid addition (Maxwell, 1968). Approximately 1 $\mathrm{g}$ of soil was finely ground in an agate mortar and weighed in an Erlenmeyer flask. Concentrated nitric acid $(25 \mathrm{~mL})$ was then added, and a Teflon stopper with a $30 \mathrm{~cm}$ long glass reflux tube was used to prevent the volatilization of As during the digestion process (adapted from Verlinden, 1982). The sample was digested at $60{ }^{\circ} \mathrm{C}$ overnight and then at $120{ }^{\circ} \mathrm{C}$ for $1 \mathrm{~h}$. The stopper was removed, and the nitric acid was evaporated to obtain a volume of approximately $5 \mathrm{~mL}$. The sample was cooled, and $5 \mathrm{~mL}$ of concentrated perchloric acid was added. Again, a Teflon stopper with a $30-\mathrm{cm}$-long glass reflux tube was used, and the sample was digested at $220^{\circ} \mathrm{C}$ for $30 \mathrm{~min}$; the nitric acid was volatilized during this stage. The sample was then cooled and filtered into a $100 \mathrm{~mL}$ volumetric flask. Quality was assured by similarly digesting in duplicate the following certified reference samples: PACS-2 obtained from the National Research Council Canada, and GRX-2 obtained from the United States Geological Survey. 
The obtained values were within $10 \%$ of the certified value. Spikes of $\mathrm{Cu}, \mathrm{Cd}, \mathrm{Pb}, \mathrm{Zn}$ and $\mathrm{As}$ were performed on every 10 th sample and recovery was $100 \% \pm 7 \%$. Total and soluble concentrations of $\mathrm{Cu}$, $\mathrm{Cd}, \mathrm{Pb}, \mathrm{Zn}$ and As were determined by atomic absorption spectroscopy.
The activity of $\mathrm{Cu}^{2+}$ was determined in the $0.1 \mathrm{M} \mathrm{KNO}_{3}$ extract with an ion selective electrode (Rachou et al., 2007). The results were expressed as $\mathrm{pCu}^{2+}$, which is the negative logarithm of the activity of free $\mathrm{Cu}^{2+}$ ion. The water holding capacity (WHC) was determined by the saturation and gravity drainage method (ISO 11269-1, 1993).

Table 1. General physicochemical properties of all studied soils $(n=87)$.

\begin{tabular}{|c|c|c|c|c|}
\hline Soil property & Unit & Median & Mean \pm SD & Range \\
\hline $\mathrm{EC}$ & $\mathrm{dS} \mathrm{m}^{-1}$ & 0.9 & $1.4 \pm 1.4$ & $0.4-9.5$ \\
\hline $\mathrm{pH}$ in $\mathrm{KNO}_{3}$ & & 7.0 & $6.9 \pm 0.6$ & $5.1-7.8$ \\
\hline $\mathrm{pCu}^{2+}$ in $\mathrm{KNO}_{3}$ & & 9.1 & $9.0 \pm 0.7$ & $6.3-10.4$ \\
\hline Organic matter & $\%$ & 3.4 & $3.8 \pm 1.9$ & $1.1-10.8$ \\
\hline Ratio $\mathrm{C} / \mathrm{N}$ & & 11 & $12 \pm 5$ & $4-35$ \\
\hline Total C & $\%$ & 2.0 & $2.3 \pm 1.2$ & $0.7-6.3$ \\
\hline Total N & $\%$ & 0.2 & $0.2 \pm 0.1$ & $0.1-0.5$ \\
\hline Sand & $\%$ & 56 & $61 \pm 20$ & $28-100$ \\
\hline Clay & $\%$ & 6 & $8 \pm 7$ & $0-28$ \\
\hline Silt & $\%$ & 35 & $31 \pm 16$ & $0-58$ \\
\hline Total $\mathrm{Cu}$ & $\mathrm{mg} \mathrm{kg}^{-1}$ & 252 & $385 \pm 441$ & $51-2878$ \\
\hline Total Cd & $\mathrm{mg} \mathrm{kg}^{-1}$ & 1.6 & $1.7 \pm 0.8$ & $0.4-5.1$ \\
\hline Total Pb & $\mathrm{mg} \mathrm{kg}^{-1}$ & 38 & $45 \pm 29$ & $19-220$ \\
\hline Total Zn & $\mathrm{mg} \mathrm{kg}^{-1}$ & 180 & $188 \pm 88$ & $79-672$ \\
\hline Total As & $\mathrm{mg} \mathrm{kg}^{-1}$ & 17 & $18 \pm 11$ & $2-60$ \\
\hline $\mathrm{Sol} \mathrm{Cu}$ & $\mathrm{mg} \mathrm{kg}^{-1}$ & 0.4 & $0.5 \pm 0.5$ & $0.05-3.1$ \\
\hline $\mathrm{Sol} \mathrm{Pb}$ & $\mathrm{mg} \mathrm{kg}^{-1}$ & 0.38 & $0.4 \pm 0.2$ & $0.00-0.6$ \\
\hline Sol As & $\mathrm{mg} \mathrm{kg}^{-1}$ & 0.02 & $0.03 \pm 0.03$ & $0.00-0.08$ \\
\hline
\end{tabular}

(EC: electrical conductivity; $\mathrm{pCu}^{2+}$ : negative logarithm of the activity of free $\mathrm{Cu}^{2+}$; $\mathrm{SD}$ : Standard deviation. Extraction ratios for $\mathrm{pH}$ and $\mathrm{pCu}$ was 1:2.5 soil/solution ratio). 


\subsection{Bioassay for determination of PNR}

The bioassay was based on ISO 15685 (2012), which specifies a rapid method to assess the potential activity of microbial nitrifying populations by determination of the rate of ammonium oxidation in soils. In a soil slurry (soil + test medium), autotrophic ammonium-oxidizing microorganisms are exposed to ammonium sulfate, while the oxidation of the nitrite is inhibited by the addition of sodium chlorate.

The bioassay was carried out with four replicates. Specifically, $25 \mathrm{~g}$ of moist soil samples were placed in 250 Erlenmeyer flaks and mixed with the test medium adjusted to give a precise total liquid volume of $100 \mathrm{~mL}$. The test medium contained $1 \mathrm{mmol} \mathrm{L}^{-1}$ $\mathrm{KH}_{2} \mathrm{PO}_{4}$ buffer, $5 \mathrm{mmol} \mathrm{L}^{-1} \mathrm{NaClO}_{3}, 1,5 \mathrm{mmol} \mathrm{L}^{-1}$ $\left(\mathrm{NH}_{4}\right)_{2} \mathrm{SO}_{4}$, and had a $\mathrm{pH}$ of approximately 7.2. Prior to the bioassay, the effect of $\mathrm{NaClO}_{3}$ was tested in different concentration to ensure effective inhibition of biological nitrate formation and not having negative effects on ammonium oxidation. An orbital shaking incubator thermostatically controlled at 25 ${ }^{\circ} \mathrm{C} \pm 2$ and with a rotation of $175 \mathrm{r} \mathrm{min}^{-1}$ was used. Erlenmeyer flasks were placed in the orbital shaking incubator using a fully randomized design. The total duration of the bioassay was 6 hours.

After $2 \mathrm{~h}$ and $6 \mathrm{~h}$ of incubation, $2 \mathrm{~mL}$ of soil slurry were taken. The samples were dispensed into test tubes and $2 \mathrm{~mL}$ of $4 \mathrm{M} \mathrm{KCl}$ were added to stop the ammonium oxidation. Then the samples were filtered using a syringe filter of $0.20 \mu \mathrm{m}$. Nitrite concentration were determined by routine methods (Sadzawka, 2006). The rate of ammonium oxidation ( $\mathrm{mg} \mathrm{NO}_{2} \mathrm{~kg}^{-1}$ of dry mass of soil $\mathrm{d}^{-1}$ ) was calculated from the difference between $\mathrm{NO}_{2}$ concentrations at different measuring times. Values of PNR can be found in Online Supplementary Table 2

\subsection{Bioassay for determination of $\mathrm{Nmin}$}

Bioassay was based on ISO 14238 (2012), which specifies laboratory procedures for measuring the mineralization of organic nitrogen by the soil microbiota. Specifically, $600 \mathrm{~g}$ of dry weight soil sample were placed in plastic containers and watered by spray with deionized water up to $60 \%$ of WHC. After $24 \mathrm{~h}$ of waiting, the soils were restructured, separated into 4 replicates of $150 \mathrm{~g}$ dry weight soil, and placed in covered plastic containers. Irrigation was carried out weekly during the testing period.

An incubator chamber was used in darkness condition at temperature of $20^{\circ} \mathrm{C} \pm 2$. The containers were placed in the incubator chamber using a fully randomized design. The total length of the test period was 48 days. At the beginning and at the end of the test period, $20 \mathrm{~g}$ of soil samples were taken. The content of ammonium $\left(\mathrm{NH}_{4}^{+}\right)$, nitrite $\left(\mathrm{NO}_{2}^{-}\right)$and nitrate $\left(\mathrm{NO}_{3}^{-}\right)$was determinate analytically (Sadzawka et al., 2006). Then, nitrogen mineralization (Nmin) was calculated from the difference between the sum of ammonium, nitrite, and nitrate at the end of the assay (day 48) and at the beginning of the assay (day 0 ). Values of Nmin can be found in Online Supplementary Table 2 .

\subsection{Statistical analysis}

Simple and multiple regressions were carried out between the biological responses and the physicochemical characteristics of the soils. Normal distribution and homogeneity of residuals were verified (Kutner et al., 2004). Statistical analyses were carried out using Minitab 17. 


\section{Results and Discussion}

\subsection{General soils properties}

The distribution of most of the variables was not normal. Thus, we present median values, along with means and standard deviations (Table 1$)$. The range of $\mathrm{pH}(6.9 \pm 0.6)$ was narrower than in other studies on the effects of metals on PNR and Nmin (Sauvé et al.,
1999, Smolders et al., 2001). The studied soils exhibited wide ranges of OM (1.1-10.8\%) and total $\mathrm{Cu}$ (51-2878 $\left.\mathrm{mg} \mathrm{kg}^{-1}\right)$. Soil OM was positively correlated with soil clay content $\left(p<0.05, \mathrm{R}^{2}=0.12\right)$. The values of soil metal concentration are higher than the reported in background values (total $\mathrm{Cu}<135 \mathrm{mg} \mathrm{kg}^{-1}$, $\mathrm{Cd}<0.31 \mathrm{mg} \mathrm{kg}^{-1}, \mathrm{~Pb}<28 \mathrm{mg} \mathrm{kg}^{-1}, \mathrm{Zn}<242 \mathrm{mg} \mathrm{kg}^{-1}$ and As $<21 \mathrm{mg} \mathrm{kg}^{-1}$ ), suggesting anthropogenic contamination (PGS, 2015, Poblete et al., 2015).

Table 2. Regression models between potential nitrification rate (PNR) ( $\mathrm{mg} \mathrm{NO}_{2} \mathrm{~kg}^{-1}$ of soil d $\mathrm{d}^{-1}$ ) and nitrogen mineralization (Nmin) ( $\mathrm{mg} \mathrm{N} \mathrm{kg}^{-1}$ of soil) in all studied soils ( $\left.\mathrm{n}=87\right)$.

\begin{tabular}{lll}
\hline Assay & Regression & $\mathrm{R}^{2}$ \\
\hline \multirow{2}{*}{ PNR } & $-23.23+4.41 \mathrm{pH}$ & 0.28 \\
& $-22.80+4.10 \mathrm{pH}+0.45 \mathrm{OM}$ & 0.32 \\
\multirow{2}{*}{ Nmin } & $-0.78+5.63 \mathrm{OM}^{*}-1.13 \mathrm{Clay}^{*}$ & 0.30 \\
& $3.09+7.02 \mathrm{OM}^{*}$ & 0.44 \\
\hline
\end{tabular}

(In multiple regressions, all variables were significant $(p<0.05)$ * Variables were slightly correlated $\left(\mathrm{p}=0.001, \mathrm{R}^{2}=0.12\right) . \mathrm{OM}=$ Organic matter (\%)).

\subsection{Effect of physicochemical properties of soils on $P N R$ and Nmin}

Regression models between PNR and Nmin and soil physicochemical properties are present in Table 2 . Values of PNR and Nmin did not correlate with each other. PNR was positively determinate by soil $\mathrm{pH}$ $\left(\mathrm{R}^{2}=0.28\right)$, despite its relative narrow range (range 5.1-7.8, average 6.9 \pm 0.6 ). In addition, OM improved the regression model $\left(\mathrm{R}^{2}=0.32\right)$, being a positively related with PNR. Similarly, Sauvé et al. (1999) indicated that the response of this bioassay was determined by $\mathrm{pH}$ (range of 3.5 to 7.8 ) and soil OM (range of 0.6 to $5.8 \%)\left(\mathrm{R}^{2}=0.43\right)$.

In contrast to PNR, Nmin was independent of soil $\mathrm{pH}$ and was positively determinate by soil OM content
$\left(\mathrm{R}^{2}=0.30\right)$. In addition, clay content was negatively related with the response and improved the regression model $\left(\mathrm{R}^{2}=0.44\right)$. Similarly, Côté et al. (2000) indicated that $\mathrm{OM}$ have a positive effect, possibly because OM has a protective effect in the soil microorganisms, while clay reduced the amount of nitrogen mineralized.

\subsection{Effects of metals on PNR and Nmin responses nor- malized by $O M$}

Considering that OM affected PNR and Nmin responses and in order to evaluate the effect of metals on microbial properties, we normalized the bioassays responses by OM. Regression models are present in Table 3. 
Table 3. Regression models between potential nitrification rate (PNR) and nitrogen mineralization (Nmin) normalized by $\mathrm{OM}\left(\mathrm{mg} \mathrm{N} \mathrm{g}^{-1}\right.$ of $\left.\mathrm{OM}\right)$ in all studied soils $(\mathrm{n}=87)$.

\begin{tabular}{lll}
\hline Assay & Regression & $\mathrm{R}^{2}$ \\
\hline \multirow{2}{*}{ PNR } & $-4.52+0.95 \mathrm{pH}$ & 0.18 \\
& $-4.71+1.01 \mathrm{pH}-0.0006 \mathrm{Cu}_{\mathrm{t}}$ & 0.22 \\
\hline \multirow{2}{*}{ Nmin } & $7.88-0.26 \mathrm{Clay}$ & 0.16 \\
& $8.71-0.27$ Clay $-0.002 \mathrm{Cu}_{\mathrm{t}}$ & 0.19 \\
\hline
\end{tabular}

(In multiple regressions, all variables were significant $(p<0.05)$. $\mathrm{CuT}=\mathrm{Cu}$ total concentration $\left(\mathrm{mg} \mathrm{kg}^{-1}\right)$ ).

PNR normalized by OM positively correlated with soil $\mathrm{pH}\left(\mathrm{R}^{2}=0.18\right)$, similar to what was obtained without normalizing by OM. In addition, inclusion of total $\mathrm{Cu}$ improved the regression model $\left(\mathrm{R}^{2}=0.22\right)$, indicating a negative effect on PNR, thus showing that $\mathrm{Cu}$ is indeed contributing to toxicity. However, total $\mathrm{Cu}$ content explain a low percentage of the variance for PNR. On the other hand, Nmin normalized by OM was negatively correlated with clay content $\left(\mathrm{R}^{2}=0.16\right)$. Although inclusion of total $\mathrm{Cu}$ improved the regression model $\left(\mathrm{R}^{2}=0.19\right)$, it explained a low percentage of the variance. In contrast to the data obtained by Dai et al. (2004) and Smolders et al. (2003), the effects of other metals were not significant.

\section{Conclusions}

Due to sensitivity of the physicochemical characteristics of the soils, the potential nitrification rate and the nitrogen mineralization had a limited applicability as soil quality indicators for metal toxicity assessment in metal-contaminated soils.

\section{Acknowledgments}

This study was funded by the FONDECYT project 1150503.

\section{References}

Adriano, D.C. 2001. Trace elements in terrestrial environments: biogeochemistry, bioavailability, and risk of metals. Springer-Verlag, New York, NY.

Aguilar, R., Hormazabal, C., Gaete, H., Neaman, A. 2011. Spatial distribution of copper, organic matter and $\mathrm{pH}$ in agricultural soils affected by mining activities. J. Soil Sci. Plant Nut. 11, 125-145.

Bhattacharyya, P., Mitra, A., Chakrabarti, K., Chattopadhyay, D.J., Chakraborty, A., Kim, K. 2008. Effect of heavy metals on microbial biomass and activities in century old landfill soil. Environ. Monit. Assess. 136, 299-306.

Côté, L., Brown, S., Paré, D., Fyles, J., Bauhus, J. 2000. Dynamics of carbon acid nitrogen mineralization in relation to stand type, stand age and soil texture in the boreal mixedwood. Soil Biol. Biochem. 32, 1079-1090.

Dai, J., Becquer, T., Rouiller, J.H., Reversat, G., Bernhard-Reversat, F., Lavelle, P. 2004. Influence of heavy metals on $\mathrm{C}$ and $\mathrm{N}$ mineralisation and microbial biomass in $\mathrm{Zn}$-, $\mathrm{Pb}$-, $\mathrm{Cu}$-, and $\mathrm{Cd}$-contaminated soils. Appl. Soil Ecol. 25, 99-109.

De Gregori, I., Fuentes, E., Rojas, M., Pinochet, H., Potin-Gautier, M. 2003. Monitoring of copper, arsenic and antimony levels in agricultural soils 
impacted and non-impacted by mining activities, from three regions in Chile. J. Environ. Monitor. 5, 287-295.

Garbisu, C., Alkorta, I., Epelde, L. 2011. Assessment of soil quality using microbial properties and attributes of ecological relevance. Appl. Soil Ecol. $49,1-4$.

Giller, K.E., Witter, E., McGrath, S.P. 1998. Toxicity of heavy metals to microorganisms and microbial processes in agricultural soils: A review. Soil Biol. Biochem. 30, 1389-1414.

Giller, K.E., Witter, E., McGrath, S.P. 2009. Heavy metals and soil microbes. Soil. Biochem. 41, 2031-2037.

Gonzalez, I., Neaman, A., Rubio, P., Cortes, A. 2014. Spatial distribution of copper and $\mathrm{pH}$ in soils affected by intensive industrial activities in Puchuncavi and Quintero, central Chile. J. Soil Sci. Plant Nut. 14(4), 943-953.

Hansson, G.B., Klemedtsson, L., Stenström, J., Torstensson, L. 1991. Testing the Influence of chemicals on soil autotrophic ammonium oxidation. Environ. Toxicol. Water Qual. 6, 351-360.

ISO 11269-1. 1993. Soil quality - Determination of the effects of pollutants on soil flora - Part 1: Method for the measurement of inhibition of root growth. International Organization for Standardization, Genève, Switzerland.

ISO 14238. 2012. Soil quality - Biological methods - Determination of nitrogen mineralization and nitrification and the influence of chemicals on these processes. International Organization for Standardization, Genève, Switzerland.

ISO 15685. 2012. Soil quality - Determination of potential nitrification and inhibition of nitrification Rapid test by ammonium oxidation. International Organization for Standardization, Genève, Switzerland.
ISO 17402. 2008. Soil quality - Requeriments and guidance for the selection and application of methods for the assessment of bioavailability of contaminants in soil and soil materials. International Organization for Standardization, Genève, Switzerland.

Kutner, M., Nachtsheim, C., Neter, J. 2004. Applied Linear Regression Models. McGraw-Hill Education, Boston. Maxwell, J.A. 1968. Rock and Mineral Analysis. Interscience Publishers, New York.

Nielsen, M., Winding, A., Binnerup, S., Hansen, B., Hendriksen, N., Kroer, N. 2002. Microorganisms as indicators of soil health. National Environmental Research Institute.

Oorts, K., Bronckaers, H., Smolders, E. 2006. Discrepancy of the microbial response to elevated copper between freshly spiked and long-term contaminated soils. Environ. Toxicol. Chem. 25, 845-853.

PGS. 2015. Muestreo de suelos para las comunas de Quintero y Puchuncaví, Región de Valparaíso.

Poblete, N., Macari, O., Rodríguez, C. 2015. Enriquecimiento y distribución espacial de arsénico en los suelos de las comunas de Quintero y Puchuncaví. Pages 288-291 in XIV Congreso Geológico Chileno. La Serena, Chile.

Rachou, J., Gagnon, C., Sauvé, S. 2007. Use of an ion-selective electrode for free copper measurements in low salinity and low ionic strength matrices. Environmental Chemistry. 4, 90-97.

Sadzawka, A. 2006. Metodos de análisis de agua para riego. Instituto de Investigaciones Agropecuarias, Santiago, Chile.

Sadzawka, A., Carrasco, A., Grez, R., Mora, G., Flores, H., Neaman, A. 2006. Metodos de análisis recomendados para los suelos de Chile. Revisión 2006. Instituto de Investigaciones Agropecuarias, Santiago, Chile. 
Sauvé, S., Dumestre, A., McBride, M., Gillett, J.W., Berthelin, J., Hendershot, W. 1999. Nitrification potential in field-collected soils contaminated with $\mathrm{Pb}$ or $\mathrm{Cu}$. Appl. Soil Ecol. 12, 29-39.

Sheldrick, B.H., Wang, C. 1993. Particle size distribution. Pages 499-511 in Soil Sampling and Methods of Analysis. M. Carter, ed. Canadian Society of Soil Science, Lewis Publishers, Boca Raton, FL, USA.

Smolders, E., Brans, K., Coppens, F., Merckx, R. 2001. Potential nitrification rate as a tool for screening toxicity in metal-contaminated soils. Environ. Toxicol. Chem. 20, 2469-2474.

Smolders, E., Buekers, J., Oliver, I., McLaughlin, M.J. 2004. Soil properties affecting toxicity of zinc to soil microbial properties in laboratory-spiked and field-contaminated soils. Environ. Toxicol. Chem. 23, 2633-2640.

Smolders, E., McGrath, S.P., Lombi, E., Karman, C.C., Bernhard, R., Cools, D., Van Den Brande, K., Van Os, B., Walrave, N. 2003. Comparison of toxicity of zinc for soil microbial processes between laboratory-contamined and polluted field soils. Environ. Toxicol. Chem. 22, 2592-2598.

Soil Survey Staff. 2003. Keys to Soil Taxonomy. 9th ed. United States Department of Agriculture, National Resourses Conservation Service, Washington, DC, USA.
Sparks, D.L., Page, A.L., Helmke, P.A., Loeppert, R.H., Soltanpour, P.N., Tabatabai, M.A., Johnson, C.T., Sumner, M.E. 1996. Methods of Soil Analysis. Part III: Chemical Methods. Soil Science Society of America Book Series No. 5. Soil Science Society of America, American Society of Agronomy, Madison, WI.

Stenberg, B., Johansson, M., Pell, M., Sjodahl-Svensson, K., Stenstrom, J., Torstensson, L. 1998. Microbial biomass and activities in soil as affected

Stuckey, J.W., Neaman, A., Ravella, R., Komarneni, S., Martínez, C.E. 2008. Highly charged swelling mica reduces free and extractable $\mathrm{Cu}$ levels in Cu-contaminated soils. Environ. Sci. Technol. 42, 9197-9202.

Verdejo, J., Ginocchio, R., Sauve, S., Salgado, E., Neaman, A. 2015. Thresholds of copper phytotoxicity in field-collected agricultural soils exposed to copper mining activities in Chile. Ecotoxicol. Environ. Saf. 122, 171-177.

Verlinden, M. 1982. On the acid decomposition of human blood and plasma for the determination of selenium. Talanta. 29, 875-882. 